\title{
ANALISIS FAKTOR-FAKTOR YANG MEMPENGARUHIKEPUTUSAN PEMBELIAN SECARA ONLINE (E-COMMERCE) (Studi Kasus pada Konsumen Shopee di Kota Banjarmasin)
}

\author{
Nia Satriani, Susiladewi, dan Erni Alfisah \\ nia.satriani@gmail.com \\ Universitas Islam Kalimantan Muhammad Arsyad \\ Al Banjari Banjarmasin
}

\begin{abstract}
The form of research used in this study is descriptive method using quantitative data analysis. Quantitative research emphasizes the analysis of numerical data (numbers) processed by statistical methods. The technique of analyzing the data used by the author is factor analysis. In this research method, researchers used the perspective of the participants as a preferred picture in obtaining research results. Data collection is done by observation, interview and Questionnaire.

The purpose of this study was to determine the effect of product quality, price, promotion, distribution, and process factors that influence the occurrence of trust in making online purchasing decisions and the most dominant factor by consumers on Shopee sites / applications in Banjarmasin city.

The results of this study suggest that product, promotion, and distribution / place factors partially have a positive effect on trust in online purchasing decisions (case studies at Shopee Consumers in Banjarmasin City), while the price factor (price) does not have a partial effect on trust in making purchasing decisions online (case study at Shopee Consumers in Banjarmasin). The results of product (product), price (promotion), promotion (promotion), and distribution / place simultaneously have an influence on online purchasing decision making (a case study at Shopee Consumers in Banjarmasin Said). The results of this study prove that Distribution / Place is the most dominant factor influencing online purchasing decisions.
\end{abstract}

Keywords: E-Commerce, Quality, Shopee. 
Volume 5 Nomor 1, April 2019

\section{PENDAHULUAN}

Perkembangan teknologi yang terjadi dalam dua dekade semenjak menginjaknya era milenial begitu pesat hingga mempengaruhi evolusi peradaban dan gaya hidup manusia. Pergerakan pertumbuhan dan perkembangan teknologi yang melingkupi komputerisasi, elektronik, telekomunikasi dan mesm menyumbang besamya pergeseran gaya hidup di masyarakat. Keefisiensian, kepraktisan, otomatisasi dan kemudahan menjadi magnet penarik terjadinya perubahan dan pergeseran gaya hidup masyarakat yang cenderung tradisional kearah gaya hidup modem dengan ketergantungannya kepada teknologi secara masif.

Revolusi Industri adalah periode terjadinya perubahan besar-besaran pada bidang pertanian, manufakur, pertambangan, transportasi dan teknologi serta memiliki dampak mendalam terhadap kondisi sosial, ekonomi, dan budaya.

Revolusi Industri 4.0 telah mengubah gaya hidup dan pola kerja manusia secara fundamental dikarenakan segala sesuatunya saat ini telah beralih menjadi sistem yang serba otomatis dan mudah. Industri saat ini telah menyentuh dunia virtual dimana istilah Internet of Things (loT) dikenal karena konektivitas manusia dengan mesin dan data sudah lumrah dan ada dimana-mana. Hal ini memunculkan prediksi dimana kedepannya akan memberikan manfaat yang besar dalam aspek kecepatan fleksibilitas produksi, peningkatan layanan pelanggan, dan peningkatan pendapatan yang barang tentu akan memberi dampak positif pada perekonomian Indonesia sendiri menyikapi Revolusi Industri 4.0 ini dengan membentuk sebuah roadmap (peta jalan) yang terintegrasi untuk pengimplementasian strategi dalam memasuki era Revolusi Industri 4.0 yang dinamakan Making Indonesia 4. 0.

Revolusi Industri 4.0 membuka lebar peluang bisnis bagi industri manapun termasuk pertumbuhan e-commerce. E-commerce atau electronic commerce adalah penjualan, pemasaran, pendistribusian barang maupun jasa dengan menggunakan media elektronik seperti televisi, internet, aplikasi daring dan media elektronik lainnya yang mana di dalamnya dapat melibatkan pertukaran data secara elektronik dan/atau transfer dana secara elektronik.

Hampir segala hal bisa ditemui dan didapatkan melalui internet. Pembeli tidak hanya mendapatkan layanan transaksi elektronik berupa jual beli barang secara daring 
Volume 5 Nomor 1, April 2019

saja namun pasar jasa secara daring pun berkembang pesat dan mengambil alih dan menggeser pasar tradisional.

Sekarang konsumen bisa membeli produk apapun dengan jumlah tak terbatas secara online. Melihat dari pesatnya pertumbuhan pelaku bisnis e-commerce itulah maka penulis tertarik untuk memperhatikan kegiatan bisnis, proses promosi dan transaksi jual beli melalui media online ini.

Hal tersebut yang menjadi latar belakang penulis melakukan penelitian tentang Bagaimana faktor kualitas produk, harga, promosi, dan distribusi berpengaruh terhadap keputusan pembelian secara online melalui aplikasi/website Shopee.

\section{TINJAUAN PUSTAKA}

Kemunculan e-commerce sudah dimulai sejak tahun 1960an saat bisnis menggunakan EDI (Electronic Data Interchange) populer. Kemudian tahun 1979, American Standards Institute mengembangkan ASC X12. ASC X12 kerap digunakan untuk saling bertukar dokumen dengan menggunakan perangkat $E$ commerce mau tidak mau mendorong kreatifitas penjual karena dampak dari kemudahan yang didapat dari sistem ini ialah persaingan yang ketat antar penjual dengan mengedepankan keunggulan penawaran dari masing-masing untuk mendapatkan konsumen,, karena kemudahan konsumen untuk memilih dan membandingkan satu produk dengan produk yang lain dari segi harga, dan kualitas tidak terbatas oleh satu penjual melainkan secara global dan tak terbatas, makahal ini memaksa penjual untuk lebih kreatif sehingga memunculkan ide-ide kreatif dan lebih beragam untuk menarik calon konsumen. Kreatifitas ini menciptakan efisiensi tinggi, terobosan inovatif dan informative, pelayanan yang cepat, lebih mudah, akurat dan aman sehingga dapat meningkatkan kepuasan para pelanggan yang berdampak kepada loyalitas pelanggan dan peningkatan pembelian konsumen.

Proses yang ada dalam E-commerce adalah sebagai berikut:

1. Presentasi elektronis (website atau aplikasi) untuk produk dan layanan.

2. Pemesanan secara langsung dan tersedianya tagihan. Pemesanan belanja dengan order form, caran y a yaitu merchant menyediakan daftar produk yang ditawarkan beserta deskripsi produknya. Di dalam orderform, terdapat dua 
Volume 5 Nomor 1, April 2019

bagian, yaitu bagian penawaran produk dan bagian jenis pembayaran. Dan pemesanan belanja dengan shopping cart yang merupakan sebuah software yang digunakan merchant untuk mempermudah para pembeli dalam memilih produk yang ingin dibeli, software ini akan melakukan kalkulasi barang yang dibeli dan total keseluruhannya biaya yang harus dibayar.

3. Otomatis account pelanggan secara aman (baik nomor rekening maupun nomor kartu kredit)

4. Pembayaran secara langsung (online) dan penanganan transaksi

\section{METODE PENELITIAN}

Bentuk penelitian yang digunakan dalam penelitian ini adalah metode deskriptif dengan menggunakan analisa data kuantitatif. Penelitian kuantitatif lebih menekankan analisa dari data-data numerik (angka) yang diolah dengan metode statistika.

Teknis analisis data yang digunakan Penulis adalah analisis faktor. Pada metode penelitian ini, peneliti menggunakan perspektif dari partisipan sebagai gambaran yang diutamakan dalam memperoleh hasil penelitian. Pengumpulan data dilakukan dengan cara observasi, wawancara dan Questionnaire.

\section{HASIL DAN PEMBAHASAN}

Hasil analisis dari faktor-faktor yang mempengaruhi konsumen untuk berbelanja secara daring melalui aplikasi maupun situs Shopee. Data penelitian dikumpukan dengan menyebar kuesioner kepada 100 responden yang pernah berbelanja di Shopee. Guna mempermudah proses analisis data dan menguji kevalidan serta kereliabelan data, penulis menggunakan bantuan program SPSS. Hasil penelitian statistik akan dijabarkan melalui penjelasan sesuai data hasil statistik.

\section{Karakteristik Responden}

Berdasarkan jenis kelamin, dari 100 orang responden terdapat 52 responden perempuan dan 48 responden laki-laki.

Berdasarkan usia, responden berusia kurang dari 25 tahun (19-24 tahun) sebanyak 43 orang, usia 25-30 tahun sebanyak 31 orang, usia 30-40 tahun sebanyak 18 orang, dan usia lebih dari 40 tahun sebanyak 40 orang. Dapat diketahui bahwa 
pengguna aplikasi belanja daring Shopee didominasioleh golongan kelompok usia dewasa muda dari usia remaja sampai dengan 30 tahun. Hal ini disebabkan karena pada usia ini merupakan usia yang paling dekat dengan teknologi dan akses internet serta pemahaman tentang perkembangan teknologi dan perubahan gaya hidup.

Berdasarkan jenis pekerjaan, 54 responden merupakan Pegawai Negeri Sipil/ Aparatur Sipil Negara, 29 orang atau 29\% responden merupakan Mahasiswa, 11 orang responden atau $11 \%$ memiliki pekerjaan sebagai pegawai swasta, $4 \%$ responden atau 4 orang responden merupakan wiraswasta, dan 2 orang responden atau 2\% nya merupakan ibu rumah tangga/ tidak bekerja. Berdasarkan data tersebut dapat diketahui konsumen Shopee di dominasi oleh PNS/ ASN dan diikuti oleh Mahasiswa. Hal itu disebabkan oleh kemudahan akses internet dan media sosial. Kelompok jenis pekerjaan ini sangat membutuhkan kemudahan dan kepraktisan. Dengan kemudahan dan kepraktisan yang ditawarkan oleh aplikasi/situs berbelanja online seperti Shopee sangat membantu dalam memenuhi kebutuhan dan gaya hidup.

\section{Pengujian Instrumen}

\section{Pengujian Validitas}

Uji validitas digunakan untuk menguji sejauh mana ketepatan alat pengukur dapat mengungkapkan konsep gejala/kejadian yang diukur. Jika $r$ hitung lebih besar dari $\mathrm{r}$ tabel dan nilai positif maka butir/pemyataan atau indikator tersebut dinyatakan valid. Jika $\mathrm{r}$ hitung $>$ dari $\mathrm{r}$ tabel (pada taraf signifikansi 5\%) maka Pemyataan tersebut dinyatakan valid.

Apabila hasil f hitung lebih besar daripada nilai f tabel dari 100 responden yaitu 0, $195 \mathrm{r}$ tabel, maka kuesioner sebagai alat pengukur dikatakan valid dan dapat dilakukan untuk analisis faktor.

2. Pengujian Reliabilitas

Pengujian terhadap reliabilitas ditujukan untuk memastikan bahwa responden benar-benar konsisten terhadap jawaban yang diberikan dalam kuisioner tersebut (Sugiyono, 2002: 97).

Teknik estimasi reliabilitas menggunakan pendekatan penyajian satu kali tes (single trial administrarion), dengan alasan pendekatan ini mempunyai 
Volume 5 Nomor 1, April 2019

nilai praktis dan efisiensi tinggi. Koefisien reliabilitas alat ukur dihitung menggunakan teknik Formula Alpha Cronbach. Reliabilitas suatu variable dikatakan handal jika memiliki nilai Cronbach's Alpha >0,6.

Tabel 1. Hasil Pengujian Reliabilitas

\begin{tabular}{llll}
\hline \multicolumn{1}{c}{ Variabel } & Cronbach's Alpha & $\begin{array}{c}\text { N of } \\
\text { Items }\end{array}$ & Keterangan \\
\hline Bebas & & & \\
\hline Produk (Product) & 0.631 & 5 & Reliable \\
Harga (Price) & 0.650 & 5 & Reliable \\
Promosi (Promotion) & 0.700 & 5 & Reliable \\
$\begin{array}{l}\text { Distribusi/Tempat } \\
\text { (Place) }\end{array}$ & 0.751 & 5 & Reliable \\
\hline & & & \\
\hline $\begin{array}{l}\text { Kepercayaan/Keputusan } \\
\text { Pembelian (Trust) }\end{array}$ & 0.794 & 5 & Reliable \\
\hline
\end{tabular}

\section{HASIL PENELITIAN DAN PEMBAHASAN}

1. Deskripsi Variabel Produk (Product)

Tabel 2. Tanggapan responden terhadap Variabel Produk

\begin{tabular}{cccccccc}
\hline \multirow{2}{*}{ NO } & \multirow{2}{*}{ PERNYATAAN } & \multicolumn{7}{c}{ SKOR } & \multirow{2}{*}{ JU } \\
\cline { 3 - 6 } & & SS & S & N & TS & STS & JUMLAH \\
\hline 1 & XI.P1 & 50 & 43 & 6 & 1 & 0 & 100 \\
2 & X1.P2 & 8 & 42 & 49 & 1 & 0 & 100 \\
3 & X1.P3 & 7 & 29 & 60 & 3 & 1 & 100 \\
4 & X1.P4 & 6 & 33 & 45 & 16 & 0 & 100 \\
5 & XI.P5 & 6 & 48 & 41 & 5 & 0 & 100 \\
\hline & TOTAL & 77 & 195 & 201 & 26 & 1 & \\
\hline
\end{tabular}

Dari lima pernyataan yang diajukan kepada 100 responden, sebagian responden sebesar 40,2\% menyatakan sikap netral atau keraguannya atas variabel produk (product) meningkatkan keputusan pembelian mereka melalui Shopee. 
2. Deskripsi Variabel Harga (Price)

Tabel 3. Tanggapan responden terhadap Variabel Harga

\begin{tabular}{cccccccc}
\hline \multirow{2}{*}{ NO } & \multirow{2}{*}{ PERNYATAAN } & \multicolumn{7}{c}{ SKOR } & \multirow{2}{*}{ JUMLAH } \\
\cline { 3 - 6 } & SS & S & N & TS & STS & \\
\hline 1 & X2.P1 & 34 & 60 & 4 & 2 & 0 & 100 \\
2 & X2.P2 & 12 & 60 & 28 & 0 & 0 & 100 \\
3 & X2.P3 & 16 & 60 & 22 & 2 & 0 & 100 \\
4 & X2.P4 & 36 & 47 & 16 & 1 & 0 & 100 \\
5 & X2.P5 & 21 & 41 & 32 & 6 & 0 & 100 \\
\hline & TOTAL & $\mathbf{1 1 9}$ & $\mathbf{2 6 8}$ & $\mathbf{1 0 2}$ & $\mathbf{1 1}$ & $\mathbf{0}$ & \\
\hline
\end{tabular}

Dari lima pernyataan yang diajukan kepada 100 orang responden, sebagian responden sebesar 53,6\% menyatakan setuju bahwa variabel harga (price) yang berasal dari harga yang variatif, kesesuaian harga dengan kualitas dan manfaat dari produk dapat meningkatkan keputusan pembelian mereka melalui Shopee.

3. Deskripsi Variabel Promosi (Promotion)

Tabel 4. Tanggapan responden terhadap Variabel Promosi

\begin{tabular}{cccccccc}
\hline \multirow{2}{*}{ NO } & \multirow{2}{*}{ PERNYATAAN } & \multicolumn{5}{c}{$\mathbf{S}$} & \multirow{2}{*}{ JUMLAH } \\
\cline { 3 - 6 } & & $\mathbf{S S}$ & $\mathbf{S}$ & $\mathbf{N}$ & $\mathbf{T S}$ & $\mathbf{S T S}$ & \\
\hline 1 & X3.P1 & 18 & 31 & 35 & 14 & 2 & 100 \\
2 & X3.P2 & 23 & 56 & 16 & 4 & 1 & 100 \\
3 & X3.P3 & 8 & 33 & 42 & 16 & 1 & 100 \\
4 & X3.P4 & 37 & 49 & 10 & 4 & 0 & 100 \\
5 & X3.P5 & 19 & 41 & 32 & 6 & 2 & 100 \\
\hline \multicolumn{2}{r}{ TOTAL } & & $\mathbf{1 0 5}$ & $\mathbf{2 1 0}$ & $\mathbf{1 3 5}$ & $\mathbf{4 4}$ & $\mathbf{6}$ \\
\hline
\end{tabular}

Dari lima pernyataan yang diajukan kepada 100 orang responden tersebut, sebagian besar responden sebesar $42 \%$ menyatakan setuju bahwa variabel Promosi (promotion) dapat meningkatkan keputusan pembelian mereka melalui Shopee. 
Volume 5 Nomor 1, April 2019

4. Deskripsi Variabel Distribusi/Tempat (Place)

Tabel 5. Tanggapan responden terhadap Variabel

Distribusi/Tempat

\begin{tabular}{cccccccc}
\hline & & \multicolumn{7}{c}{$\mathbf{S}$} & \\
\cline { 3 - 6 } NO & PERNYATAAN & SS & S & N & TS & STS & JUMLAH \\
\hline 1 & X2.P1 & 6 & 46 & 43 & 5 & 0 & 100 \\
2 & X2.P2 & 11 & 48 & 35 & 6 & 0 & 100 \\
3 & X2.P3 & 30 & 51 & 18 & 1 & 0 & 100 \\
4 & X2.P4 & 36 & 52 & 11 & 1 & 0 & 100 \\
5 & X2.P5 & 30 & 53 & 14 & 3 & 0 & 100 \\
\hline & TOTAL & 113 & 250 & 121 & 16 & 0 & \\
\hline
\end{tabular}

Dari lima pernyataan yang diajukan kepada 100 orang responden tersebut, sebagian besar responden sebesar 50\% menyatakan setuju bahwa variabel Distribusi/Tempat (place) dapat meningkatkan keputusan pembelian mereka melalui Shopee.

5. Deskripsi Variabel Distribusi/Tempat (Place)

Tabel 6. Tanggapan responden terhadap Variabel Kepercayaan/Keputusan Pembelian

\begin{tabular}{cccccccc}
\hline \multirow{2}{*}{ NO } & PERNYATAAN & \multicolumn{7}{c}{$\mathbf{S}$} & \multirow{2}{*}{ JUMLAH } \\
\cline { 3 - 6 } & SS & S & N & TS & STS & \\
\hline 1 & Y.P1 & 10 & 42 & 44 & 4 & 0 & 100 \\
2 & Y.P2 & 13 & 52 & 32 & 3 & 0 & 100 \\
3 & Y.P3 & 18 & 55 & 26 & 1 & 0 & 100 \\
4 & Y.P4 & 20 & 62 & 16 & 2 & 0 & 100 \\
5 & Y.P5 & 13 & 45 & 35 & 7 & 0 & 100 \\
\hline \multicolumn{2}{r}{ TOTAL } & 74 & 256 & 153 & 17 & 0 & \\
\hline
\end{tabular}

Berdasarkan tabel 11 tanggapan responden terhadap faktor Kepercayaan yang kemudian menjadikan keputusan pembelian konsumen secara online dapat dikatakan sangat baik untuk semua pernyataan karena sebayak 51,2\% menyatakan kesetujuannya atas pernyataan yang disampaikan. 
Volume 5 Nomor 1, April 2019

\section{Hasil Pengujian dan Analisis Data}

1. Analisa Regresi Linier Berganda

Analisa regresi linear berganda bertujuan untuk mengetahui ada atau tidaknya pengaruh dua atau lebih variabel bebas (X) terhadap variabel terikat (Y). Analisa Regresi linear berganda digunakan untuk memprediksi seberapa jauh perubahan nilai variabel terikat Kepercayaan/Keputusan Pembelian, bila nilai variabel bebas Produk (Product), Harga (Price), Promosi (Promotion), dan Distribusi/Tempat (Place) dimanipulasi/diubah dan atau dinaik-turunkan.

\section{Uji Parsial (Uji t)}

Uji $t$ merupakan pengujian yang bertujuan untuk mengetahui ada atau tidaknya pengaruh parsial (sendiri) yang diberikan variabel bebas (X) terhadap variabel terikat (Y). Dengan kata lain uji ini menguji apakah variabel Produk (Product), Harga (Price), Promosi (Promotion), dan Distribusi/Place (Place) secara masing-masing terpisah mempunyai pengaruh yang signifikan terhadap Kepercayaan/Keputusan Pembelian.

Uji t dilakukan dengan membandingkan $t$ hitung dengan $t$ tabel pada taraf nyata alpha=0,05. Uji t berpengaruh signifikan apabila hasil perhitungan t hitung lebih besar dari $t$ tabel atau probabilitas kesalahan lebih kecil dari 5\% (sig. <0,05).

Tabel 7. Hasil Uji Parsial (Uji t)

\begin{tabular}{|c|c|c|c|c|c|c|}
\hline \multicolumn{7}{|c|}{ Coe } \\
\hline & \multirow[t]{2}{*}{ Model } & \multicolumn{2}{|c|}{$\begin{array}{c}\text { Unstandardiz } \\
\text { ed }\end{array}$} & \multirow{2}{*}{$\begin{array}{r}\begin{array}{r}\text { Standa } \\
\text { rdized }\end{array} \\
\text { Beta }\end{array}$} & \multirow[t]{2}{*}{$\mathbf{t}$} & \multirow[t]{2}{*}{ Sig. } \\
\hline & & B & Std. Error & & & \\
\hline \multirow[t]{5}{*}{1} & (Constant) & -.685 & 1.842 & & -.372 & .711 \\
\hline & Produk (X1) & .342 & .097 & .287 & 3.538 & .001 \\
\hline & Harga (X2) & .111 & .108 & .094 & 1.026 & .308 \\
\hline & Promosi (X3) & .134 & .067 & .148 & 1.999 & .048 \\
\hline & Distribusi (X4) & .441 & .098 & .420 & 4.495 & .000 \\
\hline
\end{tabular}

Dari hasil pengujian parsial terhadap variabel-variabel bebas (X) yang meliputi variabel Produk, Harga, Promosi, dan Distribusi terhadap Kepercayaan/ Keputusan Pembelian Online dapat disimpulkan bahwa Variabel Produk (Xl), Promosi (X3), dan Distribusi/Tempat (X4) secara masing-masing memiliki pengaruh yang signifikan terhadap keputusan pembelian secara on line melalui Shopee di Kata Banjarmasin, sementara Factor harga (X2) diketahui tidak memiliki pengaruh terhadap keputusan 
Volume 5 Nomor 1, April 2019

pembelian secara online melalui aplikasi daring situs belanja Shopee di Kota Banjarmasin.

\section{Uji Simultan (Uji F)}

Uji F merupakan uji secara stimulan untuk mengetahui apakah variable bebas (X) Produk (Product), Harga (Price), Promosi (Promotion), dan Distribusi/Tempat (Place), secara bersama-sama/simultan mempunyai pengaruh yang signifikan terhadap (Y) Kepercayaan untuk pengambilan Keputusan Pembelian secara Online.

Dari rumus yang ada dapat dihitung nilai $\mathrm{F}$ tabel dalam penelitian dengan 100 jumlah data dan 4 variabel, maka diketahui nilai t tabel yang digunakan dalam penelitian ini adalah $\mathrm{t}$ t a bel $(4 ; 96)=2,47$.

Jika dalam penghitungannya diketahui bahwa nilai $\mathrm{F}$ hitung > F tabel maka terdapat pengaruh simultan dari seluruh variabel bebas secara bersamaan terhadap variabel terikat.

Tabel 8. Hasil Uji Simultan (Uji F)

\begin{tabular}{lcccccc}
\hline \multicolumn{7}{c}{ A } \\
\hline Model & $\begin{array}{c}\text { Sum of } \\
\text { Squares }\end{array}$ & df & $\begin{array}{c}\text { Mean } \\
\text { Square }\end{array}$ & F & Sig. \\
\hline $1 \quad$ Regression & 403.508 & 4 & 100.877 & 31.754 & .000 \\
& Residual & 301.802 & 95 & 3.177 & & \\
\multicolumn{2}{c}{ Total } & 705.310 & 99 & & & \\
\hline a. Dependent Variable: Kepercayaan (Y) \\
\hline b. Predictors: (Constant), Distribusi (X4), Promosi (X3), Produk (X1), \\
Barga (X2)
\end{tabular}

Berdasarkan output tabel anova yang diperoleh dari hasil pengolahan dan komputerisasi dengan menggunakan program SPSS versi 25, diketahui nilai signifikansi $\mathrm{X}$ secara simultan terhadap $\mathrm{Y}$ adalah sebesar $0,000<0,05$ dan nilai F hitung 31,754> 2,47 F tabel. Hal ini berarti terdapat pengaruh variabel bebas (X) secara bersama- sama/simultan terhadap variabel dependen (Y).

\section{Koefisien Determinasi (R Square)}

Koefisien determinasi merupakan besaran yang menunjukkan besamya variabelvariabel dependen yang dapat dijelaskan oleh variabel independennya. Dengan kata 
Volume 5 Nomor 1, April 2019

lain, koefisien determinasi ini digunakan untuk mengukur seberapa jauh variabelvariabel bebas dalam menerangkan variabel terikatnya.

Tabel 9 Hasil Uji Koefisien Determinasi

\begin{tabular}{lcccc}
\hline \multicolumn{5}{c}{ Model Summary } \\
\hline Model & $\mathrm{R}$ & R Square & $\begin{array}{c}\text { Adjusted R } \\
\text { Square }\end{array}$ & $\begin{array}{c}\text { Std. Error of the } \\
\text { Estimate }\end{array}$ \\
\hline 1 & $.756 \mathrm{a}$ & .572 & .554 & 1.782 \\
\hline
\end{tabular}

a. Predictors: (Constant), Distribusi (X4), Promosi (X3), Produk (X1), Harga (X2)

Hasil analisis variabel bebas terhadap variabel terikat menunjukkan bahwa nilai adjusted $R$ square sebesar 0.554 . Hal ini berarti seluruh variabel bebas yakni Produk (Product), Harga (Price), Promosi (Promotion), dan Distribusi (Place) mempunyai kontribusi secara bersama-sama/simultan sebesar 55,4\% terhadap variabel terikat (Y) yakni Keputusan Pembelian secara online sedangkan sisanya sebesar 44,6\% dijelaskan oleh faktor-faktor lain diluar dari penelitian ini. Hal ini menunjukan bahwa pengaruh antar keempat variabel kuat karena semakin besar angka $R$ Square semakian kuat pula pengarnh keempat variabel tersebut.

\section{PEMBAHASAN}

Perkembangan teknologi yang semakin mendorong dan menopang kemajuan di bidang industri dan bisnis juga turut mempengarnhi munculnya keberagaman kebutuhan dari kebutuhan mendasar sampai kebutuhan yang meningkat dan lebih tinggi. Perkembangan teknologi mendorong munculnya metode-metode barn dalam dunia ekonomi dan bisnis, menciptakan pasar-pasar barn, dan persaingan yang lebih ketat dan bebas antar penjual dan mengakibatkan munculnya altematif dan variasi pilihan yang berbagai macam bagi pembeli.

Penjual memanfaatkan media daring dan bersaing secara ketat untuk memasarkan produknya, menawarkan berbagai macam fasilitas, pilihan dan kemudahan bagi calon pembeli. Dalam membuat keputusan pembelian, calon pembeli harus jeli dalam mengevaluasi dan menimbang faktor-faktor yang muncul untuk memunculkan rasa kepercayaan dalam diri si pembeli.

Dalam penelitian ini digunakan 4P sebagai variabelnya yaitu variabel Produk (Product), Harga (Price), Promosi (Promotion), dan 
Volume 5 Nomor 1, April 2019

Distribusi/Tempat (Place) untuk mengetahui pengaruh faktor- faktor tersebut terhadap pembuatan keputusan pembelian secara online/ daring.

1. Pengaruh Produk (Product) Terhadap KeputusanPembelian Online

Berdasarkan hasil uji t variabel produk (Product) menunjukkan nilai hitung lebih besar dari ttabel $(3,538>1,998)$ dan nilai signifikan 0,001<0,05 yang berarti bahwa variabel Product (Xl) berpengaruh secara positif dan signifikan terhadap Keputusan Pembelian secara online pada Konsumen Shopee yang berada di Kota Banjarmasin.

\section{Pengaruh Harga (Price) Terhadap Keputusan Pembelian Online}

Berdasarkan hasil uji t variabel harga (Price) menunjukkan nilai t hitung lebih kecil dari t tabel (1,026>1,998) dan nilai signifikan sig. sebesar 0,308>0,05 yang berarti bahwa variabel Price (X2) tidak berpengaruh secara positif dan tidak signifikan terhadap Keputusan Pembelian secara online pada Konsumen Shopee yang berada di Kota Banjarmasin.

3. Pengaruh Promosi (Promotion) Terhadap Keputusan Pembelian Online Berdasarkan hasil uji t variabel promosi (Promotion) menunjukkan nilai t hitung lebih besar dari t tabel $(1,999>1,998)$ dan nilai sig. sebesar $0,048<0,05$ yang berarti bahwa variabel Promotion (X3) berpengaruh secara positif dan signifikan terhadap Keputusan Pembelian secara online pada Konsumen Shopee yang berada di Kota Banjarmasin.

4. Pengaruh Distribusi/Tempat (Place) Terhadap Keputusan Pembelian Online

Berdasarkan hasil uji t variabel distribusi (Place) menunjukkan nilai t hitung lebih besar dari t tabel (4,495> 1,998) dan nilai signifikan sig. sebesar $(0,000<0,05)$ yang berarti bahwa variabel Place (X4) berpengaruh secara positif dan signifikan terhadap Keputusan Pembelian secara online pada Konsumen Shopee yang berada di Kota Banjarmasin.

5. Variabel yang Paling Dominan Berpengaruh terhadap Keputusan Pembelian Online

Variabel distribusi/tempat (Place) memiliki nilai koefisien regresi sebesar 0,441, angka ini merupakan angka terbesar diantara koefisien regresi variabel lain. Variabel Distribusi/Tempat (Place) merupakan variabel yang paling dominan 
Volume 5 Nomor 1, April 2019

berpengaruh dan menjadi pertimbangan konsumen dalam memutuskan melakukan transaksi pembelian secara online.

\section{KESIMPULAN}

Berdasarkan hasil penelitian yang telah dilakukan kepada 100 orang responden, dapat ditarik kesimpulan sebagai berikut:

1. Faktor produk (product), promosi (promotion), dan distribusi/ftempat (place) secara parsial berpengaruh secara positif terhadap kepercayaan dalam pengambilan keputusan pembelian secara online (studi kasus pada Konsumen Shopee di Kota Banjarmasin), sedangkan faktor harga (price) tidak memiliki pengaruh secara parsial terhadap kepercayaan dalam pengambilan keputusan pembelian secara online (studi kasus pada Konsumen Shopee di Kota Banjarmasin).

2. Hasil penelitian faktor produk (product), harga (price), promosi (promotion), dan distribusi/ftempat (place) secara simultan memiliki pengaruh terhadap pengambilan keputusan pembelian secara online (studi kasus pada Konsumen Shopee di Kota Banjarmasin). Setelah dilakukan penelitian ini, keunggulan berbelanja secara online adalah efisiensi, kepraktisan, dan kemudahan produk sampai ditangan konsumen/pembeli.

3. Hasil penelitian ini membuktikan faktor Distribusi/Tempat (Place) merupakan faktor yang paling dominan pengaruhnya terhadap keputusan pembelian secara online. Penyebab hal ini ialah karena kemudahan dan kepraktisan yang ditawarkan oleh transaksi online, konsumen memiliki pilihan yang lebih luas dan beragam sehingga dapat membantu dalam penyediaan produk yang diinginkan dan atau dibutuhkan oleh konsumen tanpa kendala ketiadaan atau keterbatasan kesediaan.

\section{SARAN}

Berdasarkan hasil penelitian tentang analisis faktor-faktor yang mempengaruhi keputusan pembelian secara online (Studi kasus pada konsumen Shopee di Kota Banjarmasin), peneliti memberikan saran: 
Volume 5 Nomor 1, April 2019

1. Toko yang menjual produknya secara online disarankan untuk menyediakan variasi produk lengkap, dan populer sesuai dengan tren pada saat itu.

2. Toko yang menjual produknya secara online sebaiknya menyediakan informasi secara lengkap bagi konsumen baik itu informasi mengenai produk maupun identitas penjual/toko.

3. Penjual sebaiknya selalu memberikan pelayanan yang baik dan ramah serta informatif dalam menjawab pertanyaan-pertanyaan yang diajukan oleh calon pelanggan.

4. Penjual sebaiknya menyesuaikan antara harga dan kualitas produk dan melakukan promosi atas kelebihan dan keunggulannya dibandingkan toko lain baik itu secara online maupun offline.

5. Pembeli sebaiknya jeli dalam menyaring informasi atas produk yang ditawarkan dan informasi atas penjual seperti keaslian dan identitas penjual/toko.

6. Pembeli sebelum melakkan transaksi pembelian disarankan untuk membandingkan produk dari satu penjual dengan penjual lain terlebih dahulu dan meluangkan waktu untuk menyimak dan membaca ulasan dari pembeli sebelumnya serta mengajukan pertanyaan yang dirasa perlu kepada penjual atau administrator untuk lebih meyakinkan sebelum mengambil keputusan melakukan transaksi pembelian tersebut.

7. Peneliti lain selanjutnya dapat memasukkan faktor lain dalam penelitiannya, karena selain stimuli pemasaran 4P masih dapat digali lebih lanjut melalui faktor lain seperti dari segi faktor psikologis dan sosial budaya.

\section{DAFTAR PUSTAKA}

Alma, Bachari. 2009. Manajemen Pemasaran dan Pemasaran Jasa. Bandung: Alfabeta, Bandung

Lucas, Robert E., Jr. 2002. Lectures on Economic Growth. Cambridge: Harvard University Press

http://www.kemenperin.go.id/artikel/18967/Making-Indonesia-4.0:-Strategi-RI Masuki- Revolusi-Industri-Ke-4 (Siaran Pers) diakses pada tanggal (27 November 2018).

Suhari, Yohannes. 2008. "Keputusan Pembelian Secara Online dan Faktor-faktor yang mempengaruhinya". Jurnal Teknologi Informasi Dinamika Vol.13 No.2. Semarang: Universitas Stikubank Semarang 
Volume 5 Nomor 1, April 2019

Kotler, Philip. 2003. Marketing Management, 1th Edition, New Jersey

Kotler, Philip dan Gar Amstrong. 2008. Prinsip-prinsip Pemasaran. Jakarta: Gelora ilksaraPratama

Kotler, Philip dan Kevin Lane Keller. 2009. Manajemen Marketing Edisi 13. Jakarta: Erlangga

Lovelock, Christopher dan Lauren Wright. 2007. Manajemen Pemasaran Jasa Cet. II., Jakarta: Indeks

Prasetyaningtyas, Maria Lydia. 2014. Faktor-Faktor Yang Mendorong Konsumen Berbelanja Di Online Shop Facebook (Analisis Faktor yang Mendorong Konsumen yang Pernah Melakukan Transaksi Pembelian di JogjaOnline Shop Periode 2010- 2013. Skripsi. Yogyakarta: Universitas Atma Jaya Yogyakarta

Lopulalan, Arnold Leonard. 2016. Analisis Faktor-faktor yang Mempengaruhi Pembelian Secara Online Melalui Situs Lazada.co.id. Bandung: Universitas Telkom

Yazid. 2005. Pemasaran Jasa Konsep dan Implementasi Edisi 2. Jakarta: Ekonisia

Nurmadina.2016. Analisis Faktor-faktor yang Mempengaruhi Keputusan Pembelian Secara Online (Studi Kasus pada Konsumen Fashion Online di Kata Makassar). Skripsi. Makassar: UIN Alauddin Makassar

Sugiyono. 2014. Metode Penelitian Kuantitatif Kualitatif dan R\&D. Bandung: Alfabeta 